\title{
Marta Zambrzycka
}

Uniwersytet Warszawski

\section{Topos domu w powieściach Wałerija Szewczuka: „Дім на горі", „Привид мертвого дому"}

Dom to jedno z pojęć-kluczy kultury ${ }^{1}$. Jest to również - obok toposu drogi/wędrówki - kluczowa figura prozy ukraińskiego pisarza Wałerija Szewczuka. Topos domu pojawia się niemal we wszystkich powieściach tego autora, wymieńmy choćby: „Дім на горі”, „Привид мертвого дому”, „Набережна 12”, „Темна музика сосон”, „Птахи з невидимого острова”, „Сповідь”, „Тіні зникомі”, „Стежка в траві” і inne. Obraz domu jest w twórczości Szewczuka formą przestrzennego obrazowania kategorii pozaprzestrzennych ${ }^{2}$. Symbolizuje uniwersum wartości duchowych, etycznych i moralnych. Dom, rozumiany jako ośrodek duchowości, umożliwia jednostce realizację pełni swojego człowieczeństwa. Roman Korohodski w monografii „У пошуках внутрішньої людини” podkreśla ogromną rolę, jaką w twórczości Walerija Szewczuka odgrywa apologia dzieciństwa, ściśle związana z przestrzenią domu rodzinnego. Powtarzający się motyw powrotu do domu oznacza ostatni etap na drodze samopoznania i samodoskonalenia, powrót do źródeł ${ }^{3}$. Również Raisa Mowczan we wstępie do powieści „Привид мертвого дому" przypisuje toposowi domu kluczowe znaczenie w prozie ukraińskiego pisarza. Autorka pisze, iż bez względu czy dom będzie

\footnotetext{
1 U. Trojanowska, Pozaprzestrzenny model zamieszkania jako alternatywa wobec nieludzkiej rzeczywistości państwa totalitarnego - Lidia Czukowska, Zanurzenie, „Studia Literaria. Universitatis Iagellonicae Cracoviensis", 3 (2008), s. 163-171.

2 J. Łotman, Dom w Mistrzu i Małgorzacie, „Pamiętnik Literacki”, 78/4, 1987, s. $311-319$.

3 Р. Корогодський, У пошуках внутрішньої людини, Київ 2002, с. 81.
} 
przedstawiony jako ziemia obiecana, do której zmierza bohater, jako utracony raj, enklawa spokoju i bezpieczeństwa, zbudowana przez człowieka świątynia, czy też jako zniewalająca przestrzeń bolesnych wspomnień, jest zawsze symbolem samego człowieka, jego wewnętrznego świata i duchowego rozwoju. Autorka pisze:

дім як осередя й носій автентичної подоби людини, ії̈ внутрішнього, істинного єства; це дім як внутрішній диктат і рушій ії вчинків; це дім як земля обітована, єдиний захисний притулок заблуклому в просторі мандрівникові; врешті, це дім як збудований людиною храм, що може зберегтись, а може й бути понівеченим, втраченим навіки. Але завжди для Шевчука цей дім є уособленням і часткою самої людини, без якої вона не відбудеться, не реалізується на цій землі, врешті, без якої не можна пізнати, зрозуміти цю людину4

Będąc obrazem symbolicznym odwołującym się do sfery duchowej, odzwierciedleniem wartości niematerialnych i figurą struktury psychologicznej bohatera, dom w powieściach Wałerija Szewczuka staje się archetypem, który poza wymiarem indywidualnym, nabiera szerszej, ponadindywidualnej wymowy łącząc się z kategorią pamięci historycznej. W wątku powrotu do rodzinnego domu autor koduje apologie powrotu do kulturowych i narodowych korzeni. Tak dzieje się choćby w powieści „Тіні зникомі”, gdzie pisząc o losach jednostek Walerij Szewczuk tworzy panoramę życia narodu ukraińskiego ${ }^{5}$. Natalia Horodniuk podkreśla, iż podstawową funkcją, jaką autor przypisuje przeszłości - rozumianej zarówno jako historia jednostki, jak i szerszej zbiorowości - jest poczucie zakorzenienia, które umożliwia zarówno identyfikację osobistą jak i kulturowo-narodową. Badaczka stwierdza: У свойй же художній прозі митещь прагне заповнити лакуни, що утворилися, відновити иілісність структури української культурної ідентичності, подаючи власний варіант інтерпретачії необхідних структурних ланок ${ }^{6}$.

W niniejszym tekście przeanalizuje znaczenia symboliczne domu w dwóch powieściach: „Дім на горi” oraz „Привид мертвого дому”. Utwory te - napisane w różnych okresach twórczych pisarza i zróżnicowane pod względem literackiej konwencji - łączy centralna figura domu rodzinnego,

\footnotetext{
4 Р. Мовчан, Світ ніколи не впіймає його, [в:] Привид мертвого дому, Київ 2005, c. 12 .

5 Л. Тарнашинська, Художня галактика Валерія Шевчука, Київ 2001, с. 195.

6 Н. Городнюк, Знаки необарокової культури Валерія Шевчука: компаративні аспекти, Київ 2006, с. 8.
} 
przedstawionego bądź jako uświęcona przestrzeń, oaza i schronienie przed chaosem świata, a także miejsce magiczne ( „Дім на горі”), bądź jako mroczna, prześladująca bohatera przestrzeń dzieciństwa, wspomnienie której jest zniewalające i bolesne („Привид мертвого дому”). W wymienionych utworach zbliżona jest konwencja czasowa - autor kreuje ją jako rodzaj mitycznego bezczasu. Dom jest przestrzenią, w której wydarzenia zostały zatrzymane, czy to ze względu na cykliczność rozgrywających się w nim wydarzeń, czy z powodu obsesyjnego kierowania myśli w przeszłość i powracania do tego, co już nie istnieje. W obu powieściach dom stanowi centralną figurę wokół której organizowane są wspomnienia, dążenia, wartości i tęsknoty bohaterów, jednak przedstawiony został w odmiennych konwencjach, nawiązujących bądź do obrazów Raju („Дім на горi”), bądź piekła („Привид мертвого дому”). W powieści Дім на горi dom przedstawiony jest jako rajska oaza, łącząca rzeczywistość realną z elementami baśni, mitu, legendy.

Powieść „Дім на горi” składa się z dwóch części: powieści-preambuły, opowiadającej historię czterech pokoleń mieszkańców żytomierskiego domu. Przedział czasowy tej części obejmuje lata 1911-1963. Część druga to cykl folklorystycznych opowiadań, swoistego „tekstu w tekście”, będącego zapiskami jednego z bohaterów powieści-preambuły. Całość, określana jako powieść-ballada nawiązuje do ukraińskiego folkloru i mitologii słowiańskiej. Wydany w 1983 roku utwór powstawał na przestrzeni kilku dziesięcioleci. Już w latach sześćdziesiątych zostały napisane niektóre opowiadania, włączone później do drugiej części książki. Pierwsza część - tak zwana powieść-preambuła jest chronologicznie późniejsza, autor napisał ją na początku lat osiemdziesiątych jako uzupełnienie i dopełnienie opowiadań. Polskie wydanie książki ukazało się w tłumaczeniu Jerzego Litwiniuka w 1989 roku. Skoncentruję się wyłącznie na pierwszej części utworu, w którym przestrzeń domu odgrywa kluczowe znaczenie.

Najważniejszym domem powieści jest ten tytułowy, znajdujący się na wzgórzu i będący rodzinną siedzibą kilku pokoleń kobiet, których historia cyklicznie się powtarza. Ważny jest jednak również dom, w którym mieszka para bohaterów-staruszków Iwan z Marią a następnie młode małżeństwo Chłopca z Neoniłą. Również w nim historia bohaterów jest powtarzalna, młode pokolenie odtwarza drogę życiową starszego i ostatecznie osiada w tej samej co starsi przestrzeni. Oba domy zostały przedstawione jako zatopione w bujnej zieleni, pełne wspomnień i ciepła miejsca, w których człowiek może odnaleźć nie tylko spokój, ale również osiągnąć mądrość i zrozumieć własną historię. Cykliczność czasu fabularnego, a także przedstawienie domu z jednej strony jako zacisza, enklawy spokoju, z drugiej zaś jako źródła mą- 
drości i duchowej pełni sprawia, iż można uznać je za przestrzeń o cechach sakralnych, wzorcowych, której struktura jest zgodnie z ustaleniami Mircei Eliadego odzwierciedleniem rajskiego archetypu ${ }^{7}$. Istotne, że w powieści właściwie nie znajdujemy opisów wyglądu wspomnianych domów. Dowiadujemy się jedynie, że są stare - stanowią siedzibę pokoleń - otoczone ogrodami, niemal zatopione w zieleni. O domu na wzgórzu wiemy, że rośnie przy nim ogromny, rozłożysty kasztan, posadzony w dzień ślubu jednej z mieszkanek - Babci. Częściami domu, o których autor wspomina najczęściej, są: ganek (miejsce wieczornych rozmów bohaterek), biblioteka (miejsce refleksji, lektury, a niekiedy również rozmów). Oczywiście, w powieści pojawiają się wzmianki o innych pomieszczeniach domu (sypialnia Babci, pokój Hali), nie znajdziemy tu jednak właściwie żadnych opisów wystroju wnętrz, mebli, architektury. Elementami konstrukcyjnymi, o których autor wspomina najczęściej, są okna - często otwarte, przez które rozciąga się widok na ogród, wzgórza, drogę czy miasto w dolinie. Brak szczegółowych opisów wnętrza i budowy domu - będącego wszak centralną figurą powieści - dowodzi, iż jest on przede wszystkim przestrzenią wartości, niosąca znaczenia symboliczne. Wygląd budynku nie ma większego znaczenia.

W opisach obu wspomnianych domów (a zwłaszcza otaczających je ogrodów) można dostrzec nawiązania do symboliki rajskiej. Biorąc pod uwagę, iż wydarzenia opisane w utworze rozgrywają się niedługo po zakończeniu II wojny światowej, spokój tych zielonych oaz nabiera głębszego znaczenia i jawi się jako rajska enklawa pośród chaosu. Ta rajska konotacja rozszerza się w powieści na całe miasteczko, w którym rozgrywają się wydarzenia. O panujących w nim ciszy i spokoju dowiadujemy się już w pierwszych zdaniach tekstu ${ }^{8}$. W powieści nie pada nazwa miasta, jednak domyślamy się, iż jego prototypem jest Żytomierz, w którym Walerij Szewczuk urodził się i dorastał, i który niewątpliwie pozostał dla niego rodzajem zmitologizowanej, wyidealizowanej małej ojczyzny, domem, do którego autor powraca i w którym umiejscawia wiele ze swoich fabuł.

Dom, w którym mieszka stary filozof Iwan wraz ze swoją żoną Mariją, został opisany jako cichy, otoczony sadem i ogrodem, panuje w nim obfitość dojrzałych owoców, zgodnie wspólistnieją ludzie i zwierzęta. Na werandzie gości wita mądra, spokojna gospodyni z tacą pełną soczystych jabłek, gruszek i śliwek: Вони сидітимуть тоді у садку, Марія Яківна поставить перед ним вазу з ясно - жовтими буравийями, майже прозорими сли-

7 M. Eliade, Obrazy i symbole, Warszawa 1998, s. 28.

8 В. Шевчук, Дім на горi, Київ, 1983, с. 4. 
вами та ніжношкурими грушами, Літатимуть довкола оси й сідатимуть на ті такі осяйні під сонцем плодия. Albo:

Ще тільки світало, коли він вийшов на веранду, Сад і зілля навколо були всипані міріадами іскор, і все від них аж посивіло, Сонце тільки - но зійшло над горою, але промені його ще не доходили сюди (...) Він (...) ішов садовою доріжкою і мимохідь вимічав величезні, вкриті росою буравиці в траві. Вернувся по кошик і назбирав його повний. Яблука були жовті, бокаті й пахли так ніжно, що на серці старого стало тепло ${ }^{10}$.

Obfitość drzew owocowych, a także mleka, które dają zamieszkujące gospodarstwo kozy, składają się na sugestywne i plastyczne przedstawienie przestrzeni, nawiązującej do obrazu Raju biblijnego. Jean Delumeau w „Historii Raju" podkreśla, że starotestamentowy Eden był miejscem stworzonym przez wydzielenie konkretnego ziemskiego obszaru, a charakterystycznymi jego cechami była zgoda między ludźmi i zwierzętami, spokój, obfitość natury, łagodny klimat: Na tym błogosławionym obszarze bujność natury taczyła się z obfitościa wody, z pięknymi zapachami, z wiosenna tagodnościa klimatu, kiedy (...) ludzie żyli w zgodzie ze zwierzętami ${ }^{11}$. Również Stanisław Kobielus podkreśla, iż biblijny Raj stanowił uporządkowaną przestrzeń, gdzie między stworzeniami panowała harmonia ${ }^{12}$.

Dom ten jest również celem życiowej tułaczki męskich bohaterów powieści, staje się więc rodzajem ziemi obiecanej czy mitycznej Itaki. Zarówno Iwan jak i Chłopiec, są filozofami i wędrownymi poszukiwaczami mądrości. Ich wędrówki kończą się powrotem do domu, który umożliwia im spokojne przemyślenie zdobytej wiedzy, zapewnia godziny spędzone na skupionym pisaniu, czytaniu dzieł Skoworody. Ten dom stanowi również przestrzeń, w której rozkwita prawdziwa, głęboka miłość, pełna poświęcenia, wyrozumiałości i dobroci. Kluczowa jest tu refleksja Iwana, który konstatuje iż: miłość, o której tyle rozmyślał i o której czytał w dziełach filozofów, znajduje się tuż obok, w jego własnym domu, w codzienności spędzanej z żoną: Іван тоді зрозуміє, що любов, про яку він стільки міркував $i$ яку добачав у кожній живій істоті, звела найкоштовніше гніздо перш за все в його подвір' 'ín

9 Ibidem, s. 172.

10 Ibidem, s. 186

11 J. Delumeau, Historia Raju, Warszawa 1996, s. 10.

12 S. Kobielus, Człowiek i ogród rajski w kulturze religijnej średniowiecza, Warszawa 1997 , s. 80.

13 В. Шевчук, Дім на горi..., s. 116. 
Drugi z opisanych w powieści domów: tytułowy dom na wzgórzu jest również przestrzenią sakralizowaną, jednak mniej tu nawiązań do biblijnego Raju, więcej zaś do słowiańskiej demonologii oraz struktur myślenia mitycznego. Dom stoi na wysokim, stromym wzgórzu, z którego rozciąga się widok na malowniczą dolinę miasteczka. Rośnie przy nim wielkie, stare drzewo. Zarówno wzgórze jak i drzewo stanowią bezpośrednie odwołanie do wyobrażeń o tak zwanym centrum świata, określanego przez religioznawców jako axis mundi (osią/pępkiem/centrum świata). Jest to miejsce zetknięcia trzech obszarów - nieba, ziemi i świata podziemnego ${ }^{14}$. Właśnie w domu na wzgórzu dochodzi do spotkania bohaterów z istotami demonicznymi. Sakralny wymiar przestrzeni podkreśla również cykliczność czasu, który dla mieszkańców (a właściwie dla mieszkanek) domu biegnie inaczej niż w zwykłym świecie. Kategoria czasu, będąca jednym z najważniejszych elementów konstrukcyjnych powieści, organizuje ich losy w powtarzające się cykle śmierci i narodzin, starości i młodości. Koniec jednego cyklu oznacza początek kolejnego. Wieczne odtwarzanie tej samej historii przypisane jest w powieści przede wszystkim postaciom kobiecym, których życie upływa w przestrzeni domu. Jedna z bohaterek - Babcia w następujący sposób opisuje rodzinną historię:

Чоловіки сюди приходять... вони піднімаються знизу і, як правило, просять напитися води. Той, хто нап'ється з наших рук, переступає цей поріг і залишається в домі назавжди. Так було в моєї бабуні, в моєї матері і в мене. Так було і в матері твоєї, так повинно статись і з тобою...Мені бракує розуму, щоб все це пояснити, але так воно траплялося... ${ }^{15}$

Bezustannie powtarzająca się historia mieszkanek domu na wzgórzu sprawia, iż czas zostaje zatrzymany, zastygły. Dom jest też przestrzenią zdecydowanie kobiecą, mężczyźni uciekają z niego, ponieważ - jak konstatuje Hala - nie są w stanie wytrzymać tego bezruchu i ciszy. Historia domu na wzgórzu wprowadza czytelnika w atmosferę baśni, sam budynek staje się areną tajemniczych, powtarzalnych wydarzeń:

над усім цим домом і справді зависла особлива таємниця, бо й дім цей по-справрзньому непростий. Проглядала ту кількакрат повторену історію, наче кіно: (...) й цей дім, повторений кількаразово, (...) щоразу стояла коло того дому інша дівчина, власне, дівчина була одна, але одягнута в одежу залежно від часу, в якому жила ${ }^{16}$.

14 O sakralnej symbolice przestrzeni w powieści Dom na wzgórzu, a także innych utworów Wałerija Szewczuka pisałam w monografii Sacrum $i$ profanum w prozie Wałerija Szewczuka, Warszawa 2015.

15 В. Шевчук, Дім на горi..., с. 73.

16 Ibidem, s. 52. 
Jednak tytułowy dom ma w powieści również inne znaczenia, nie związane z kompleksem wyobrażeń folklorystycznych. Jest przestrzenią wartości, w której kształtuje się osobowość bohaterek. Dom to miejsce dzieciństwa, dorastania, młodości, starości. Dom to przestrzeń, w której bohaterki przeżywają najsilniejsze uczucia, miłość, rozpacz, samotność. W przestrzeni domu kształtuje się również ich intelekt. Hala spędza długie godziny czytając w domowej bibliotece, a lektury pomagaja jej zrozumieć świat i sformować własny światopogląd. Dzięki doborowi lektur, należących przede wszystkim do kanonu literatury ukraińskiej, młoda dziewczyna poznaje historię i system wartości rodzimej kultury:

Дівчина пішла в кімнату, де містилась у них бібліотека, зібрана дідом i батьком, сіла у зручний фотель і взяла до рук книжку. Була то одна із найспокійніших книжок - дореволюційний том Нечуя-Левицького, читала неспішливі потоки слів, які грали, наче переливна вода, і це так дисонувало з тим, що робилося в її серці, що вона відклала книжку, взявши до рук томик Кобилянської ${ }^{17}$.

Lub: Галя примостилася коло лампи із розгорненою "Повією" Панаса Мирного ${ }^{18}$.

Zamiłowanie Hali do czytania odróżnia ją od pozostałych kobiet, zamieszkujących dom: Ми, жінки чього дому, майже ніколи не поділяли пристрасті наших прийшлих чоловіків до книжок. Крім того, тут майже все украӥнські книжки - не зовсім весела лектура для дівчат. (...) Знаєш, я не прочитала звідси жодної книжки ${ }^{19}$.

Dom to również przestrzeń, w której ożywają losy poprzednich pokoleń, a historia, przekazywana w opowieściach Babci, staje się częścią życia młodej Hali. W powieści powtarzają się opisy wieczornych rozmów w zaciszu oświetlonego jedną lampac pokoiku, lub nocne, letnie wspomnienia na ganku, podczas których Babcia wprowadza Halę w dzieje rodziny. Dziewczyna początkowo broni się przed tą wiedzą, uważając ją za starcze fantazje babci, jednak los pokoleń staje się również jej udziałem. W pewnym momencie Hala zaczyna rozumieć, jak ważna jest dla niej zarówno przeszłość rodziny, jak i przestrzeń własnego domu, będąca częścią jej duszy, obiektem miłości i przywiązania:

\footnotetext{
17 Ibidem, s. 49.

18 Ibidem, s. 61.

19 Ibidem, s. 50.
} 
Вона теж несла в собі ті ж таки гени, тому й любила цю спокійну й таку величну стару, любила цей дім і всі речі в ньому, світло його кімнат і запахи. Любила цей каштан серед двору, посаджений у день бабчиного весілля, і дерева інші, посаджені в день весіль інших дівчат, вона любила і всіх тих уже неіснуючих у світі сутньому, перед якими все-таки носить певні зобов'язання ${ }^{20}$.

Z pojęciem domu łączą się więc również takie kategorie, jak: zakorzenienie, poczucie tożsamości, świadomość samego siebie, swego pochodzenia i przynależności kulturowej. Dom to nie cztery ściany i dach - o czym świadczy brak opisów wyglądu budynku - lecz przestrzeń wartości, w której jednostka kształtuje własne człowieczeństwo, uczy się szacunku do przeszłości, miłości i dobroci. Dom jest więc kategorią zarówno „zewnętrzną” jak i „wewnętrzną" - domem jest nie tylko przestrzeń, ale również duchowe uniwersum, wypracowane przez każdego człowieka. W połączeniu z rajską symboliką obu opisanych wyżej domów powstaje całościowa wizja domu, wyraźnie nawiązująca do skoworodiańskiej koncepcji „ogrodu serca” ${ }^{21}$.

Odmienne przedstawienie domu znajdujemy w powieści „Привид мертвого дому", w której nie stanowi on przestrzeni rajskiej czy źródła moralnych wartości, lecz jest mrocznym, zniewalającym i niszczącym swoich mieszkańców mikrokosmosem oraz prześladującym wspomnieniem. Na całość powieści „Привид мертвого дому” składają się opowiadania pisane w przeciągu kilkudziesięciu lat: od 1986-2000. Ta powieść w opowiadaniach zbudowana jest z pięciu części, których motywem przewodnim jest uwikłanie w przeszłość i jej niszczycielski wpływ na ludzką psychikę. O ile opisane wyżej domy z powieści „Дім на горi” stanowiły sakralizowaną przestrzeń najczystszych wartości, sprawiających, że życie bohaterów nabierało pełni i bezpośrednio nawiązujących do obrazów Raju, w drugim utworze mamy do czynienia z symboliką śmierci, cierpienia, moralnej degradacji. Figurę domu w powieści „Привид мертвого дому” można odczytać jako obraz piekła miejsca wiecznego potępienia ${ }^{22}$. Przeszłość, ujęta w figurę martwego domu wywiera na bohaterów destrukcyjny i w efekcie uśmiercający wpływ. Obsesyjne powracanie we wspomnieniach do tej przestrzeni jest wewnętrzną koniecznością bohatera, wiąże się jednak z bólem i poczuciem wewnętrznej pustki. Narrator powieści stwierdza, że dom tkwi w jego sercu jak wbity gwóźdź, od którego nijak nie można się uwolnićé23.

20 Ibidem, s. 67.

21 Р. Корогодський, У пошуках внутрішньої людини, Київ 2002, с. 67.

22 G. Minois, Historia piekta, Warszawa, 1998, s. 79.

23 В. Шевчук, Привид мертвого дому, Київ 2005, с. 23. 
W tej powieści - przeciwnie niż w poprzednio opisanej - znajdujemy dokładne opisy architektury i wyglądu tytułowego domu. Zawiera on wzmianki o ilości pięter, o dachu, ścianach i okiennicach, a także klatki schodowej, przybudówek. Jest też informacja o jego lokalizacji - stoi on, co znamienne, pod wzgórzem, które samo w sobie wzbudza niepokój, gdyż jest „najeżone” skałkami przypominającymi zęby. Dowiadujemy się także, iż budynek jest stary i musiał służyć kilku pokoleniom mieszkańców. Jest także położony na uboczu, odosobniony:

двоповерховий, із бляшаним дахом і з кількома коминами на ньому, з вікнами, затуленими віконницями, з лівого й правого крила в нього дощаті прибудови: входи зі сходами на другий поверх - у галереї, яка також покрита старою бляхою. [...] Дім стояв під горою, в якій де-не-де виступали скельки - як зуби; найближчі сусіди [...] жили метрів за сто чи й більше. [...] він [...] пережив, очевидно, кілька людських поколінь, бо, судячи зі стилю, коли те будування можна назвати стилем, простояв на своєму місці років зі сто 24 .

Ramę przestrzenną powieści stanowią same mury domu - wzmaga to wrażenie ograniczenia, zamknięcia. Wydaje się, że poza tymi murami nie istnieje żadna znacząca dla fabuły rzeczywistość. Okna budynku nie otwierają się - jak było to w poprzedniej powieści - na bujny, zalany słońcem i zielenią ogród, nie roztacza się za nimi szeroka panorama, obiecująca wolność, radość i możliwość nowych budujących doświadczeń. Tu za oknami rozciąga się pustka. Dom jest przedstawiony jako martwa strefa z wyraźnie oznaczonymi granicami (teren podwórka, oddalenie od innych zabudowań). Martwota owa ma dwa wymiary - po pierwsze, dom jest jedynie wspomnieniem - w czasie fabularnym już nie istnieje, a opisywane wydarzenia są retrospekcją, określaną przez narratora mianem „widma”. Po drugie, martwota domu związana jest z jego mroczną, wręcz piekielną symboliką. Jest to przestrzeń, w której zło dominuje nad dobrem, jego mieszkańcy to w większości ludzie zdegenerowani, ułomni pod względem intelektualnym, moralnym i duchowym. Charakterystyczne, że dom jako przestrzeń antywartości ma moc zniewalającą i ograniczającą bohaterów. Zawężenie przestrzeni dotyczy zarówno dorosłych jak i dzieci. Te ostatnie nie mają prawa opuszczać pobliża budynku, о czym wspomina bohater: я не мав права виходити з двору; може, тому, думається тепер, той мертвий дім $і$ дорослому мені не дає спокою, ніби приріс до мене ${ }^{25}$. Dorośli spędzają w murach

24 Ibidem, c. 23.

25 Ibidem, c. 27. 
domu czas wolny od pracy, jest to jednak przeważnie czas wykorzystany na kłótnie i animozje, lub poświęcony alkoholowym libacjom. Rysuje się więc obraz domu jako przestrzeni zniewalającej bohaterów, dla których stanowi on jedyną możliwą przestrzeń życia. Jest to literacki obraz piekła - umiejscowiony na pustkowiu, martwy, będący dla mieszkańców rodzajem więzienia i przestrzenią cierpienia. Chciałoby się w tym miejscu zastąpić określenie „dom” innym, zawierającym mniejszy ładunek aksjologiczny - np. „budynek” czy nawet „blok”. Nie robię tego, ponieważ, po pierwsze, sam autor w tytule powieści używa określenia „dom”, po drugie zaś, obraz wykreowanej przez niego przestrzeni jest paradoksalny - pomimo zdecydowanie negatywnej symboliki stanowi przestrzeń znaczącą, istotną dla wspomnień i osobowości bohaterów.

Przewaga elementów negatywnych w symbolice powieściowego domu przedstawiona została za pomocą historii poszczególnych bohaterów. Są to przeważnie opowieści smutne, niekiedy dramatyczne, mroczne bądź zawstydzające. Jest w nich fizyczna przemoc, moralne znęcanie się nad bliskimi, alkoholizm, apatia, rezygnacja oraz zdrada małżeńska. Wiele z tych historii ukazuje postaci uosabiające dobro jako przegrane w konfrontacji z bohaterami negatywnymi. Ta przegrana może mieć wymiar moralny lub oznaczać fizyczne zniszczenie - śmierć. Dominacje zła w przestrzeni domu podkreśla fakt, że dotyka ono również najmłodszych mieszkańców dzieci. Przykładem może być rodzina Waszczuków, w której rozgrywa się symboliczna walka dobra ze złem wcielona w postaci dwójki dzieci: Stasi i Wiktora. Stasia stanowi wcielenie elementu pozytywnego, jest dziewczynką cichą, dobrą, łagodną i zupełnie nie pasującą do pozostałych członków rodziny, zwłaszcza zaś do swojego brata Wiktora, antypatycznego, niedorozwiniętego, agresywnego chłopca. Wiktor znęca się nad Stasią fizycznie i psychicznie:

сестру свою він люто ненавидів і вряди-годи на нього нападав сказ; без будь-якої причини, дико заревівши, він нападав на закляклу біля підручників дівчинку i, хриплячи й завиваючи, бив іiі, рвучи на ній одежу. Стася тоді якось тонко, як поранене звіреня, вищала, і той вискіт був такий пронизливий, що його, мабуть, було чутно в кожному кутикові дому ${ }^{26}$.

Dom w tej powieści jest również przestrzenią, w której przeszłość zlewa się w jedno z teraźniejszością wywołując wrażenie bezruchu. Konstrukcja czasowa jest ściśle związana z symboliką domu, który w tym przypadku

26 В. Шевчук, Привид мертвого дому, с. 32. 
oznacza przeszłość, to, co już nie istnieje, jest martwe, a pomimo to wciąż prześladuje i więzi człowieka. Czas w „martwym domu” krąży po zamkniętym kole, z którego udało się wyrwać jedynie narratorowi. Raisa Mowczan pisze: минуле мертве, але воно неминуче може переслідувати людину $і$ впливати на ї̈ теперішне життя 27 ; dalej autorka podkreśla, że uwięzienie w przeszłości - przedstawione w obrazie martwego domu - ma niszczący wpływ na ludzką psychikę i duszę, martwy dom ma moc niszczenia ludzkich dusz ${ }^{28}$. Obraz tej przestrzeni można określić, za Urszulą Trojanowską figurą antydomu - przestrzenią śmierci, niemożliwą do zamieszkania/zakorzenienia. Przebywająca w tej przestrzeni grupa ludzi stanowi antywspólnotę29. Idąc za tym tropem, można powiedzieć, że każda poszczególna historia kreuje obraz antyrodzinny, nawiązuje więc do perspektywy odwrócenia znaczeń, kreuje tym samym obraz świata nieludzkiego, stanowiącego zaprzeczenie ładu kulturowego i moralnego. Ten obraz piekła na ziemi wpisuje się $\mathrm{w}$ tradycje obrazowania antydomów czy pseudodomów w literaturach słowiańskich. Jurij Łotman zwracał uwagę na infernalną symbolikę antydomów w prozie Michaiła Bułhakowa. Ten wybitny literaturoznawca przeciwstawiał literackie obrazy „Domu żywych” obrazom „antydomu pseudożywych" 30. Poszerzając zasadę odwrócenia można stwierdzić, iż w obrazie martwego domu Szewczuk kreuje obraz łotmanowskiej antykultury, „kultury ze znakiem ujemnym”, czy „kultury na opak”, w obrazie której następuje odwrócenie wartości ${ }^{31}$.

W powieści „Привид мертвого дому” obraz domu jest jednak paradoksalny. Pomimo swojej „martwoty” i bez wątpienia destrukcyjnego wpływu na życie bohatera pozostaje jednocześnie symbolem jego duchowej więzi z własną przeszłością, miejscem, z którego rozpoczyna się życiowa droga i do którego bohater powraca we wspomnieniach, szukając bezskutecznie ratunku przed samotnością i pustką świata. Tę niejednoznaczność widać w ostatniej części powieści, w której narrator otrzymuje list z informacją o zburzeniu „martwego domu” (będącego jednocześnie jego „domem rodzinnym"). Zamiast spodziewanej ulgi odczuwa paradoksalny żal za tym,

27 Р. Мовчан, Світ ніколи не впіймае його, с. 13.

28 Ibidem, s. 13.

29 U. Trojanowska, Od domu ku antydomowi, w: Archetyp domu w dwudziestowiecznej literaturze rosyjskiej. Lidia Czukowska, Jurij Trifonow, Anatolij Pristawkin, Kraków 2008, s. $61-119$.

30 J. Łotman, Dom w Mistrzu i Małgorzacie, „Pamiętnik Literacki” 1987, 78/4, s. $311-319$.

31 J. Lotman, O semiotycznym mechanizmie kultury, [w:] Semiotyka kultury, wybór i opracowanie Elżbieta Janus i Maria Renata Mayenowa, Warszawa 1975, s. 147-170. 
co utracone, za miejscem, które - jakkolwiek mroczne i nędzne by nie było - ukształtowało jego wspomnienia. Ta część powieści nosi symptomatyczną nazwę "Collapsus" (Zapaść), a jej motywem przewodnim jest narastająca samotność bohatera w świecie. Roman Korohodski podkreśla, iż w twórczości Wałerija Szewczuka jednym z kluczowych jest motyw powrotu do domu. Powrót ten stanowi dopełnienie wędrówki, zarówno tej, rozumianej dosłownie jako przemieszczanie się w czasie, jak również symbolicznej podróży w głąb siebie, w poszukiwaniu wewnętrznych wartości. Dom, rozumiany jako źródło duchowych wartości pozwala powracającemu wędrowcowi zrozumieć rolę zakorzenienia $\mathrm{w}$ uniwersum kulturowych tradycji i osobistego samodoskonalenia. Ta symbolika nie dotyczy jednak omawianej wyżej powieści, w której dom nie jest przestrzenią wartości, lecz rodzajem anty-przestrzeni. Ruina tego domu, jego zniszczenie, które uniemożliwia bohaterowi powrót, jest jednocześnie sugestią, iż powrót taki nie byłby możliwy nawet w sytuacji, gdyby budynek stał nadal - nie ma w nim bowiem i nie było niczego, do czego warto powracać. Duchowa podróż bohatera nie może zakończyć się w miejscu naznaczonym destrukcją i śmiercią, oznaczałoby to bowiem jego klęskę.

Przeanalizowane wyżej utwory to jedynie dwa z wielu przykładów toposu domu w twórczości Wałerija Szewczuka, autora zanurzonego w uniwersum ukraińskiej kultury i tradycji. Ryzykując pewne uogólnienie można stwierdzić, że w większości jego utworów pojęcie „dom” jest ściśle związane ze sferą moralnych, duchowych, narodowych i kulturowych wartości. Jest figurą silnie związaną z kategoriami zakorzenienia, samoświadomości, pamięci historycznej, nawiązuje też do filozoficznych koncepcji budowania przez jednostkę wewnętrznego uniwersum moralnego, owego wspomnianego przez Hryhorija Skoworode „ogrodu serca”. Dom to kategoria nie tyle fizyczna, zewnętrzna, co wewnętrzna, związana z najgłębszą istotą człowieka, sferą jego norm i wartości. Jednak aby spełniać tę rolę dom musi być ,żywy", musi żyć historią swoich mieszkańców, sąsiadów, okolicy, ziemi. Martwa, przepełniona pustką i złem przestrzeń będąca bardziej „budynkiem” niż „domem” rodzi jedynie destrukcję bohatera, jak widać na przykładzie powieści „Привид мертвого дому".

\section{I T E R A T U R A}

Городнюк Н., Знаки необарокової культури Валерія Шевчука: компаративні аспекти, Київ 2006.

Корогодський Р., У пошуках внутрішньої людини, Київ 2002. 
Мовчан Р., Світ ніколи не впіймае його, [в:] Привид мертвого дому, Київ 2005.

Тарнашинська Л., Художня галактика Валерія Шевчука, Київ 2001.

Шевчук В., Привид мертвого дому, Київ 2005.

Шевчук В., Дім на горі, Київ 1983.

Delumea S., Człowiek i ogród rajski w kulturze religijnej Średniowiecza, Warszawa 1997.

Eliade M., Obrazy i symbole, Warszawa 1998.

Łotman J., Dom w Mistrzu i Matgorzacie, „Pamiętnik Literacki” 1987, 78/4.

Łotman J., O semiotycznym mechanizmie kultury, (w:) Semiotyka kultury, wybór i opracowanie Elżbieta Janus i Maria Renata Mayenowa, Warszawa 1975.

Minois G., Historia piekta, Warszawa 1998.

Trojanowska U., Od domu ku antydomowi, w: Archetyp domu w dwudziestowiecznej literaturze rosyjskiej. Lidia Czukowska, Jurij Trifonow, Anatolij Pristawkin, Kraków 2008.

Trojanowska U., Pozaprzestrzenny model zamieszkania jako alternatywa wobec nieludzkiej rzeczywistości państwa totalitarnego - Lidia Czukowska, Zanurzenie, „Studia Literaria. Universitatis Iagellonicae Cracoviensis”, 3(2008).

Zambrzycka M., Sacrum i profanum w prozie Wałerija Szewczuka, Warszawa 2015.

P E 3 Ю $\mathrm{M}$

\section{ТОПОС ДІМУ У РОМАНАХ ВАЛЕРИЯ ШЕВЧУКА:} "ДІМ НА ГОРІ", "ПРИВИД МЕРТВОГО БУДІНКУ"

Дім, це одне з ключових понять культури. Символ дому є також одним 3 найважливіших у прозі українського письменника Вулерія Шевчука. Літературний топос дому з'являється майже у всіх романах цього автора. Образ дому в творах Шевчука символізує всесвіт духовних, етичних та моральних цінностей. В творчості цього автора дім має різноманітну символіку та різні значення: це "обіцяна земля", "втрачений рай", "анклав миру та безпеки", "храм духовних цінностей" але також простір болючих, негативних спогадів, Але, головне, що дім у творчості Шевчука, це перед усім символ самої людини, iї внутрішнього світу. У цьому тексті я аналізую топос дому в двох романах: "Дім на горі" та "Привид мертвого будинку"

Ключові слова : будинок, ідентичність, українська проза, історія, культура. 


\section{S U M M A R Y \\ THE TOPOS OF HOME IN V. SHEVCHUK'S NOVELS "HOUSE ON THE HILL" AND "SPECTER OF THE DEAD HOUSE"}

Home - one of the key concepts of culture - occupies an important place in the prose of a Ukrainian writer Walery Shevchuk. Literary topos of home appears in almost all his novels. The image of home in Shevchuk's works symbolizes the universe of spiritual, ethical and moral values. It is understood in various ways: as a "promised land" where a hero goes, as a "lost paradise", as an enclave of peace and security, as a man-made temple, or as a space of painful negative memories, In all of these ways there is a symbol of man, his inner world. In this text I analyze the symbol of home in two novels: "House on the Hill" and "Specter of the Dead House".

Key words: home, identity, Ukrainian prose, history, culture. 